\title{
Primary Productivity and Precipitation-Use Efficiency in Mixed-Grass Prairie: A Comparison of Northern and Southern US Sites
}

\author{
Lance T. Vermeire, ${ }^{1}$ Rod K. Heitschmidt, ${ }^{2}$ and Matthew J. Rinella ${ }^{3}$ \\ Authors are ${ }^{1,3}$ Rangeland Ecologists and ${ }^{2}$ Supervisory Rangeland Scientist (retired), US Department of Agriculture, Agricultural Research Service, \\ 243 Fort Keogh Rd, Miles City, MT 59301, USA
}

\begin{abstract}
Precipitation-use efficiency (PUE) is a key determinant of aboveground net primary production (ANPP). We used long-term datasets to contrast ANPP and PUE estimates between northern (southeast Montana) and southern (north Texas) mixed-grass prairies. Effects of varying amounts and temporal distribution of precipitation on PUE were examined at the Montana site, using a rainout shelter and irrigation. Results show that 1) ANPP was $21 \%$ less in Montana than Texas $\left(188 \mathrm{~g} \cdot \mathrm{m}^{-2}\right.$ vs. 237 $\left.\mathrm{g} \cdot \mathrm{m}^{-2}\right)$; 2) plant function type (PFT) composition varied between the two study locations, with cool-season perennial grasses (CSPG) dominating in Montana (52\%) and warm-season perennial grasses (WSPG) dominating in Texas (47\%); 3) production dynamics varied between the two sites with $90 \%$ of ANPP completed by 1 July in Montana as compared to 31 August in Texas; 4) average PUE estimates were greater in Montana $\left(0.56 \mathrm{~g}\right.$ dry matter $\cdot \mathrm{m}^{-2} \cdot \mathrm{mm}^{-1}$ of precipitation) than Texas $(0.40$ $\mathrm{g} \cdot \mathrm{m}^{-2} \cdot \mathrm{mm}^{-1}$ ); and 5) contributions to PUE estimates varied among PFT and location, with CSPG estimates being greater in Montana than Texas (52\% vs. $31 \%$ ) and WSPG estimates being greater in Texas than Montana (47\% vs. $27 \%$ ). Seasonal droughts and supplemental irrigations at the Montana site substantially altered ANPP, PFT biomass composition, and PUE. Results show PUE was responsive to PFT composition relative to amount and seasonal distribution of precipitation. Therefore, one should expect changes in ANPP and PUE to occur with shifts in precipitation patterns until PFT composition becomes adjusted to the regime.
\end{abstract}

\section{Resumen}

La eficiencia del uso de la precipitación (PUE) es una clave determinante de la producción primaria aérea neta (ANPP). Utilizamos una base de datos para contrastar estimaciones de ANPP y PUE entre (el suroeste de Montana) y el sur de los pastizales mixtos (norte de Texas). El efecto de la variación y la cantidad en la distribución temporal de la vegetación en PUE se examinaron en el sitio de Montana, utilizando un refugio para la lluvia e irrigación. Los resultados muestran que: 1) ANPP fue $21 \%$ menor en el sitio de Montana, que en el sitio de Texas $\left(188 \mathrm{~g} \cdot \mathrm{m}^{-2}\right.$ vs. $\left.\left.237 \mathrm{~g} \cdot \mathrm{m}^{-2}\right) ; 2\right)$ la composición de los tipos funcionales de las plantas (PFT) varía entre las dos localidades, especies de gramíneas perenes de crecimiento de invierno (CSPG) dominaron en el sitio de Montana (52\%) y gramíneas perenes de crecimiento de verano (WSPG) dominaron en el sitio de Texas (47\%); 3) La dinámica de la producción varía entre los dos sitios con $90 \%$ de ANPP concluido para el 1 de Julio en Montana, comparado al 31 de Agosto en Texas; 4) el promedio de la estimación de PUE fue mayor en Montana (0.56 g de materia seca $\cdot \mathrm{m}^{-2} \cdot \mathrm{mm}^{-1}$ de precipitación) que en Texas $\left(0.40 \mathrm{~g} \cdot \mathrm{m}^{-2} \cdot \mathrm{mm}^{-1}\right)$; y 5$)$ las contribuciones a las estimaciones de PUE varían entre PFT y la del sitio, con una estimación CSPG mayor en Montana que en Texas (52\% vs. 31\%) y la estimación WSPG mayor en Texas que en Montana (47\% vs. $27 \%$ ). Las sequias estacional y la irrigación suplementaria en el sitio de Montana significativamente altera ANPP, la composición de la biomasa de PFT, y PUE. Estos resultados demuestran que PUE fue receptivo a la composición de PFT relativo a la cantidad y la distribución estacional de la precipitación. Por lo que uno debe esperar que ocurran cambios en ANPP y PUE con modificaciones en los patrones de la precipitación hasta que la composición de PFT se ajuste al sistema.

Key Words: climate change, drought, grassland, precipitation-use efficiency, primary production, rangeland, water

Research was conducted under a cooperative agreement between US Dept of Agriculture (USDA)-Agricultural Research Service and the Montana Agricultural Experiment Station. Mention of a proprietary product does not constitute a guarantee or warranty of the product by USDA, Montana Agricultural Experiment Station, or the authors, and does not imply its approval to the exclusion of other products that also might be suitable.

US Dept of Agriculture-Agricultural Research Service Northern Plains Area is an equal opportunity/affirmative action employer and all agency services are available without discrimination.

Correspondence: Dr Lance Vermeire, Agricultural Research Service, 243 Fort Keogh Road, Miles City, MT 59301 USA. Email: lance.vermeire@ars.usda.gov

Manuscript received 3 December 2007; manuscript accepted 25 March 2009.

\section{INTRODUCTION}

Precipitation is a primary determinant of the structure and function of terrestrial ecosystems (Webb et al. 1978, 1983) such as the grasslands of the Great Plains (Rosensweig 1968; Lauenroth 1979; Rutherford 1980; Le Houerou et al. 1988; McNaughton et al. 1993; Lauenroth et al. 1999). Precipitationuse efficiency (PUE) as calculated (annual aboveground net primary production [AANP] divided by annual precipitation from Le Houerou 1984) for indigenous grasslands generally has 
been observed in the range of $0.5-2.0 \mathrm{~g}$ dry matter production $\cdot \mathrm{m}^{-2} \cdot \mathrm{mm}^{-1}$ of annual precipitation (Noy-Meir 1973; Sims and Singh 1978; Smoliak 1986; Sala et al. 1988; Lauenroth and Sala 1992; Epstein et al. 1998; Paruelo et al. 1999; Lauenroth et al. 2000; O'Connor et al. 2001). These same observations have shown that PUE estimates differ within and between grasslands because of differences in an array of factors, including amount and temporal distribution of annual precipitation, soil texture and water holding capacity, plant species composition, seral stage, basal cover, and previous year's production. Ultimately, these factors affect PUE through alterations in evapotranspiration rate, the dominant process by which grassland precipitation is returned to the atmosphere (Wilcox et al. 2006). Similar relationships have been demonstrated across an array of agro-ecosystems (Hatfield et al. 2001; Nielsen et al. 2005), forests, and deserts (Webb et al. 1978, 1983).

Temperature can have significant effects on PUE through its influence on evapotranspiration rates. Additionally, temperature is known to interact with precipitation in controlling the relative abundance of $\mathrm{C}_{3}$ and $\mathrm{C}_{4}$ grasses. The abundance of $\mathrm{C}_{4}$ grasses is positively correlated with minimum daily July temperature (Teeri and Stowe 1976) and mean annual temperature (Lauenroth et al. 1999). Yet, annual precipitation is more strongly correlated than temperature to ANPP at sites with less than $500 \mathrm{~g} \cdot \mathrm{m}^{-2}$ (Huxman et al. 2004). $C_{4}$ plants are more water-efficient than $C_{3}$ plants (Caldwell et al. 1977). However, this advantage in water-use efficiency can be overwhelmed by the seasonal distribution of available soil water (Winslow et al. 2003) and greater evapotranspiration rates when comparing actual production per unit of precipitation in $\mathrm{C}_{3^{-}}$and $\mathrm{C}_{4}$-dominated communities across opposite ends of a temperature gradient. For example, Monson et al. (1986) observed that peak leaf expansion for the $\mathrm{C}_{3}$ western wheatgrass (Pascopyrum smithii [Rydb.] A. Love) and $\mathrm{C}_{4}$ blue grama (Bouteloua gracilis [Willd. ex Kunth] Lag. ex Griffiths) coincided during June in northern mixed-grass prairie and that water-use efficiency was similar between species during that period. Although water-use efficiency of blue grama was more than twice that of western wheatgrass with warmer conditions of July, it still was less than it had been during June and peak leaf expansion. Therefore, the advantage in water-use efficiency can be limited to less productive periods and might not yield the differences in season-long production expected between a $\mathrm{C}_{3}$ and $\mathrm{C}_{4}$ grass based on water-use efficiency at any one time.

Our objectives were to contrast the temporal and spatial dynamics of ANPP and PUE between northern $\mathrm{C}_{3}$-dominated (Montana) and southern $\mathrm{C}_{4}$-dominated (Texas) mixed-grass prairies and to determine the effects of precipitation amount and seasonal distribution on ANPP and PUE at the Montana site. We hypothesized that differences in ANPP and PUE were functions of the amount and seasonal distribution of precipitation relative to plant functional type composition.

\section{METHODS}

\section{Study Sites}

Four studies (Table 1) were conducted $12 \mathrm{~km}$ south of Miles City, Montana (lat $46^{\circ} 22^{\prime} \mathrm{N}$, long $105^{\circ} 5^{\prime} \mathrm{W}$ ) at the US Department of Agriculture-Agricultural Research Service Fort Keogh Livestock and Range Research Laboratory (LARRL).
Three studies conducted between 1993 and 2004 were located on a single site and one study was conducted in 1992 on a second site $0.5 \mathrm{~km}$ away. LARRL is located in the Great PlainsPalouse Dry Steppe Province (Bailey 1995). Topography ranges from rolling hills to broken badlands intersected with small streams and a broad, nearly level river valley. Climate is continental and semiarid. Annual precipitation averages 343 $\mathrm{mm}$, with about $60 \%$ of precipitation received during the 150 day, mid-April to mid-September growing season (Fig. 1). Average daily temperatures range from a high of $23^{\circ} \mathrm{C}$ in July to a low of $-8^{\circ} \mathrm{C}$ in January. Annual evaporation from nearby Fort Peck Lake (lat $47^{\circ} 56^{\prime} \mathrm{N}$, long $106^{\circ} 25^{\prime} \mathrm{W}$ ) is about $57 \mathrm{~cm}$ (Frederick 1993). Vegetation is a mixed-grass complex (Table 2) interspersed with very light to moderate stands of Wyoming big sagebrush (Artemisia tridentata subsp. wyomingensis Beetle \& Young). Soils at both Montana sites were deep clays and clay loams.

Three of the Texas study sites were located on or adjacent to the Texas Experimental Ranch (TER) near Throckmorton, Texas (lat $33^{\circ} 20^{\prime} \mathrm{N}$, long $\left.99^{\circ} 14^{\prime} \mathrm{W}\right)$, with the remaining site located about $100 \mathrm{~km}$ north on the W. T. Waggoner Estate Ranch, near Vernon, TX (Vernon; lat $33^{\circ} 50^{\prime} \mathrm{N}$, long $99^{\circ} 25^{\prime} \mathrm{W}$; Table 1). All sites were located in the Southwest Plateau and Plains Dry Steppe and Shrub Province (Bailey 1995). Regional topography is rolling plains consisting of broad river valleys and gentle slopes leading to nearly level uplands. Climate is continental and semiarid. Mean annual precipitation was $680 \mathrm{~mm}$ at the TER (1961-1988) and $652 \mathrm{~mm}$ at Vernon (1938-1980). Rainfall is bimodally distributed with peaks in June and September (Fig. 1). Average daily temperatures range from a high of $29^{\circ} \mathrm{C}$ in July to a low of $4^{\circ} \mathrm{C}$ in January. Annual evaporation from nearby Lake Kemp (lat $33^{\circ} 45^{\prime} \mathrm{N}$, long $99^{\circ} 13^{\prime} \mathrm{W}$ ) is about $152 \mathrm{~cm}$ (Joerns 1961). Native vegetation at all sites was a mixed-grass complex interspersed with open-canopy stands of honey mesquite (Prosopis glandulosa Torr. var. glandulosa). The major difference in plant species composition between the sites was the TER site was dominated by a mix of Texas wintergrass, sideoats grama, and buffalograss, whereas the overwhelming dominant at Vernon was buffalograss (Table 2). Soils at both sites were deep clays, clay loams, and silty clay loams.

\section{Datasets}

Vegetation data used were collected and published over a 26-yr period by the second author and associates (Table 1). Datasets are from two multiyear and two single-year studies conducted in Montana and four multiyear studies conducted in Texas. Total number of treatment-by-year datasets was 76, with 54 from Montana and 22 from Texas.

Because multiple treatments were often applied simultaneously on a single site, amount and seasonal patterns of annual precipitation were often the same for one or more treatments. Therefore, only 28 monthly precipitation datasets were necessary to describe annual precipitation regimens associated with the 76 ANPP datasets; 11 from Texas and 17 from Montana. Growing season (April through October) precipitation data were collected on site at Miles City, MT and Vernon, TX, whereas late autumn, winter, and early spring estimates were derived from National Oceanic and Atmospheric Administration [NOAA; 1978-2005] records (NOAA 1988, 2004). All precipitation data for TER datasets were collected on site. 
Table 1. Description of datasets used in study.

\begin{tabular}{|c|c|c|c|c|}
\hline Location & Years & Treatments & $\begin{array}{l}\text { No. of } \\
\text { datasets }\end{array}$ & Reference \\
\hline \multicolumn{5}{|c|}{ I. Montana (northern mixed-grass prairie) } \\
\hline A. LARRL $^{1}$ & 1992 & Clay pan and silty range sites & 2 & Heitschmidt et al. (1995) \\
\hline B. LARRL & 1994-1995 & $\begin{array}{l}5 \text { simulated drought-grazing treatments and an } \\
\text { ambient ungrazed control }\end{array}$ & 24 & Heitschmidt et al. (1999) \\
\hline C. LARRL & 1998-2001 & $\begin{array}{l}5 \text { simulated drought-grazing treatments and an } \\
\text { ambient, ungrazed control }\end{array}$ & 24 & Heitschmidt et al. (2005) \\
\hline D. LARRL & 2004 & $\begin{array}{l}3 \text { simulated drought-irrigation treatments and an } \\
\text { ambient control }\end{array}$ & 4 & Heitschmidt and Vermeire (2006) \\
\hline \multicolumn{5}{|c|}{ II. Texas (southern mixed-grass prairie) } \\
\hline A. TER $^{2}$ & $1978-1979$ & A rotational grazing system and an ungrazed control & 4 & Heitschmidt et al. (1982) \\
\hline B. Vernon ${ }^{3}$ & 1979-1980 & $\begin{array}{l}\text { Herbicide treatment of Prosopis glandulosa and } \\
\text { an untreated control }\end{array}$ & 4 & Heitschmidt et al. (1986) \\
\hline C. TER & $1981-1984$ & Simulated $14-$ and 42 -pasture rotational grazing & 8 & Heitschmidt et al. (1987) \\
\hline D. TER & $1986-1988$ & $\begin{array}{l}\text { Grass only and grass }+P \text {. glandulosa in nonweighing } \\
\text { lysimeters }\end{array}$ & 6 & Heitschmidt and Dowhower (1991) \\
\hline
\end{tabular}

${ }^{1}$ US Department of Agriculture-Agricultural Research Service Fort Keogh Livestock and Range Research Laboratory, Custer County, Montana (lat $46^{\circ} 22^{\prime} \mathrm{N}$, Iong $105^{\circ} 5^{\prime}$ W).

${ }^{2}$ Texas Experimental Ranch, Throckmorton County, Texas (lat $33^{\circ} 20^{\prime} \mathrm{N}$, long $99^{\circ} 14^{\prime} \mathrm{W}$ ).

${ }^{3}$ W. T. Waggoner Ranch, 9-Mile Research Site, near Vernon, Wilbarger County, Texas (lat $33^{\circ} 50^{\prime} \mathrm{N}$, long $\left.99^{\circ} 25^{\prime} \mathrm{W}\right)$.

\section{Data Development and Summarization}

Two datasets were developed for analyses: one comparing Montana to Texas mixed-grass prairie, and the other exploring
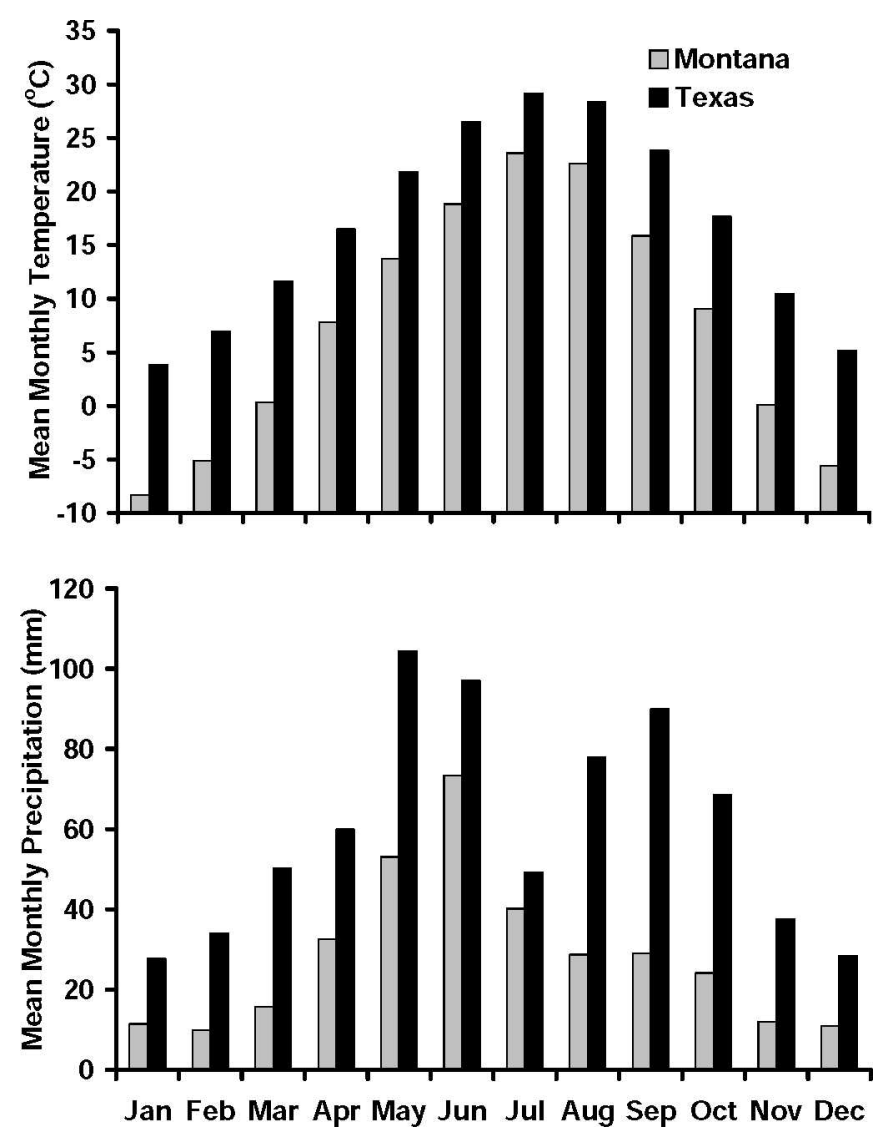

Figure 1. Mean monthly temperature $\left({ }^{\circ} \mathrm{C}\right)$ and precipitation $(\mathrm{mm})$ for Miles City, Montana (1936-2004) and Throckmorton, Texas (19311988) based on long-term weather records (NOAA 1988, 2004). the effects of simulated drought-irrigation treatments in Montana. Data from simulated treatments were excluded from comparisons between Montana and Texas, leaving 58 ambient precipitation datasets (36 from Montana and 22 from Texas).

The Montana-only data included all treatment-level data excluded from the Montana vs. Texas dataset plus paired ambient treatments for a total of 72 datasets. All treatments had six replicates each for drought vs. nondrought contrasts in 1994 and 1995 (Heitschmidt et al. 1999) and 1998-2000 (Heitschmidt et al. 2005), and three replicates each for four drought-irrigation treatments (ambient precipitation, spring drought + ambient summer precipitation, ambient spring precipitation + summer irrigation, and spring drought + summer irrigation) in 2004 (Heitschmidt and Vermeire 2006). Drought was imposed late May through September 1994, April through June 1998 and 1999, and May through June 2004. Data also were collected 1 yr following 1994, 1998, and 1999 treatments. Summer irrigation in 2004 resulted in the addition of $76 \mathrm{~mm}$ of water in July and $76 \mathrm{~mm}$ in August.

ANPP was estimated by plant functional type (PFT), which was comprised of cool-season, $\mathrm{C}_{3}$ perennial grasses (CSPG); warm-season, $\mathrm{C}_{4}$ perennial grasses (WSPG); cool-season, $\mathrm{C}_{3}$ annual grasses (CSAG); and forbs (FORB), predominantly cool-season, $\mathrm{C}_{3}$ annuals (Paruelo and Lauenroth 1996). ANPP estimates were derived from monthly clipping of aboveground biomass during the growing season. Specifically, estimates from the Texas studies were based on the sum of temporal increases in either live + recent dead tissue (current year's production) or total standing crop. Montana estimates were based on the sum of temporal increases in live biomass. Previous research has shown ANPP estimates vary as a function of methodology, but magnitude of differences between these three methods in mixed-grass prairie have been shown to be generally $<10 \%$ (Singh et al. 1975). Total production was estimated by summing individual PFT estimates. PUE (g dry matter $\cdot \mathrm{m}^{-2} \cdot \mathrm{mm}^{-1}$ precipitation) was estimated by dividing 
Table 2. Description of vegetation at three study sites. ${ }^{1}$

\begin{tabular}{|c|c|c|}
\hline Study & Functional type & Dominant herbaceous vegetation \\
\hline \multirow{7}{*}{ I. Montana } & CSPG & Western wheatgrass (Pascopyrum smithii [Rydb.] A. Love) \\
\hline & & Needle-and-thread (Hesperostipa comata [Trin. \& Rupr.] Barkworth) \\
\hline & WSPG & Blue grama (Bouteloua gracilis [Willd. ex Kunth] Lag. ex Griffiths) \\
\hline & CSAG & Japanese brome (Bromus japonicus Thunb.) \\
\hline & FORB & Woolly plantain (Plantago patagonica Jacq.) \\
\hline & & Western salsify (Tragopogon dubius Scop.) \\
\hline & & Common dandelion (Taraxacum officinale F. H. Wigg.) \\
\hline \multicolumn{3}{|l|}{ II. Texas } \\
\hline \multirow[t]{6}{*}{ A. TER } & CSPG & Texas wintergrass (Nassella leucothrica [Trin. \& Rupr.] Pohl) \\
\hline & WSPG & Sideoats grama (Bouteloua curtipendula [Michx.] Torr.) \\
\hline & & Buffalograss (Buchloe dactyolides [Nutt.] J. T. Columbus) \\
\hline & CSAG & Japanese brome \\
\hline & FORB & Texas broomweed (Amphiachyris amoena [Shinners] Solbrig) \\
\hline & & Heath aster (Symphyotrichum ericoides [L.] G. L. Nesom) \\
\hline \multirow[t]{7}{*}{ B. Vernon } & CSPG & Texas wintergrass \\
\hline & WSPG & Buffalograss \\
\hline & CSAG & Little barley (Hordeum pusillum Nutt.) \\
\hline & & Japanese brome \\
\hline & FORB & Texas broomweed \\
\hline & & Woolly plantain \\
\hline & & Heath aster \\
\hline
\end{tabular}

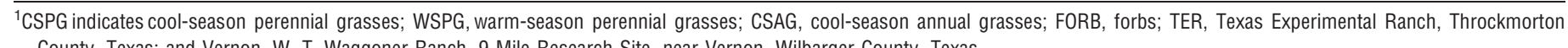
County, Texas; and Vernon, W. T. Waggoner Ranch, 9-Mile Research Site, near Vernon, Wilbarger County, Texas.

ANPP estimates by annual precipitation. PUE of individual PFT were converted to their respective percent contribution to total PUE. Root biomass was not collected or used in estimates of production. Because of temporal differences in growing seasons, the Montana precipitation year was defined as 1 November through 31 October and the Texas precipitation year was defined as 1 January through 31 December.

\section{Statistical Analyses}

Absolute $\left(\mathrm{g} \cdot \mathrm{m}^{-2}\right)$ and relative (percent composition) ANPP and associated annual PUE were compared using analysis of variance models (SAS 1990) with location (Texas vs. Montana) and PFT within location as main effects. One-way analysis of variance models were used to test for differences between locations in total (sum of PFT) ANPP and PUE estimates. Analyses were limited to annual means because seasonal analyses were not interpretable due to our inability to quantify the intraseasonal impacts of carry-over soil water on ANPP and PUE estimates.

Effects of Montana drought-irrigation treatments on ANPP and PUE contributions were assessed using drought treatment, PFT, and years as main effects for 1994-1995 and 1998-2000 multiyear datasets. A separate model was used to analyze 2004 data, using PFT and drought-irrigation treatment as main effects. Means from significant $(P<0.05)$ main and interaction effects were separated using tests of simple effects.

We used a hierarchical normal linear regression model to estimate the percent of annual biomass production occurring by 1 July and 1 September. The model structure was as follows:

$$
\log \operatorname{it}\left(P_{i j}\right)=\ln \left(\frac{P_{i}}{1-P_{i}}\right)=Y_{i}+\beta T+\varepsilon_{i j}
$$

where $P_{i j}$ is the proportion of total biomass produced by day $T$ during the $i^{\text {th }}$ year $(Y)$ and $j^{\text {th }}$ unit, and $\varepsilon_{i j} \sim N\left(0, \sigma^{2}\right)$ is measurement error. Because the response variable is a proportion, the logit transformation helped in meeting normality assumptions, but results were back-transformed to ease interpretation. After fitting Equation 1 and computing percent-to-date estimates, we solved for $T$ and computed date-to-percent estimates (dates by which $75 \%$ and $90 \%$ of biomass was produced). Random effects were omitted from Equation 1 in simulating quantities of interest to evaluate temporal differences between sites and among plant groups averaged over all years.

We used a fully Bayesian approach to estimate the joint posterior distribution of regression model parameters. Thus, assigning prior distributions to the parameters was a necessary step in our analysis. Commonly used noninformative prior distributions were assigned to $\beta$ and $\sigma^{2}$. A normal prior was assigned to the year effects, and this prior's mean $(\mu)$ and variance $\left(\tau^{2}\right.$; i.e., hyperparameters) were estimated from the data in the manner described by Gelman et al. (2004).

Markov Chain Monte Carlo integration (i.e., Gibbs sampler) was used to simulate the posterior distributions. Given our normality assumptions, the conditional distributions needed for the integration were in close form. The position parameters $(\beta$, $\mu)$ were normal, whereas the dispersion parameters $\left(\sigma^{2}, \tau^{2}\right)$ were inverse chi-square (Gelman et al. 2004). To simulate the posterior distribution, sample statistics were assigned as starting values and the parameter values were repeatedly updated by drawing sequentially from the conditional posterior distributions of position and dispersion parameters. A Markov chain consisting of 200000 draws for each parameter was 
constructed and the first 100000 draws were discarded as burn-in. To ensure convergence was achieved, we constructed a second chain and compared the resulting parameter estimates to those acquired with the first chain. A FORTRAN 6.6.a program was developed to perform all computations (Digital Visual Fortran 2000). By inserting drawn posterior distribution values into Equation 1, probability distributions were estimated for all quantities of interest and summarized by their $2.5 \%$, $50 \%$, and $97.5 \%$ quantiles.

\section{RESULTS}

\section{Precipitation}

Variation in annual precipitation across years was similar between sites with CVs of $19 \%$ and $16 \%$ for Montana and Texas, respectively. Montana average precipitation during the $1992-2004$ study period was $7 \%$ below ( $319 \mathrm{~mm}$ vs. $343 \mathrm{~mm}$ ) the long-term (1936-2004) average, whereas Texas average precipitation during the 1978-1988 study period was 6\% above $(676 \mathrm{~mm}$ vs. $634 \mathrm{~mm})$ the long-term (1931-1988) average. As a percentage of the long-term average, Montana annual precipitation ranged from $71 \%$ to $146 \%$ (244 $\mathrm{mm}$ to $500 \mathrm{~mm}$ ) and Texas precipitation ranged from 74 to $141 \%$ $(470 \mathrm{~mm}$ to $895 \mathrm{~mm})$. Intensity of precipitation events during study periods was markedly less $(P<0.01)$ in Montana than Texas in that annual averages for 1) maximum amounts of precipitation received in a single day were $31 \mathrm{~mm}$ and $82 \mathrm{~mm}$; 2) number of days with more than $2.54 \mathrm{~mm}$ total precipitation were 32 and 44 ; 3) number of days with more than $12.7 \mathrm{~mm}$ total precipitation were 7 and 17; and 4) number of days with more than $25.4 \mathrm{~mm}$ total precipitation were 1 and 7 , respectively. Although runoff was not measured, each of these figures indicates more potential for precipitation loss in Texas.

\section{Aboveground Net Primary Production}

Total ANPP was about $21 \%$ greater in Texas $\left(237 \mathrm{~g} \cdot \mathrm{m}^{-2}\right)$ than Montana $\left(188 \mathrm{~g} \cdot \mathrm{m}^{-2}\right)$. Cool-seasonal perennial grass production was greater in Montana $\left(99 \mathrm{~g} \cdot \mathrm{m}^{-2}\right)$ than Texas (68 $\left.\mathrm{g} \cdot \mathrm{m}^{-2}\right)$, whereas WSPG production was greater in Texas (109 $\left.\mathrm{g} \cdot \mathrm{m}^{-2}\right)$ than Montana $\left(54 \mathrm{~g} \cdot \mathrm{m}^{-2}\right)$. There were no differences in CSAG or FORB production $\left(23 \mathrm{~g} \cdot \mathrm{m}^{-2}\right)$ either within or between locations. Percent composition of CSPG was greater in Montana $(52 \%)$ than Texas $(31 \%)$ and WSPG composition was greater in Texas $(47 \%)$ than Montana (27\%). Composition was similar between CSAG and FORB and across locations $(11 \%)$.

Analyses of the temporal ANPP dynamics revealed some differences among functional groups within and between locations. The proportional amount of total annual biomass produced by 1 July tended to be greater in Montana (90\%) than Texas $(74 \%)$. However, there were no within-group differences between locations by 1 July, with CSPG, WSPG, CSAG, and FORB production averaging $78 \%, 67 \%, 83 \%$, and $75 \%$, respectively. Proportional ANPP by 1 September differed between sites for total production $(99 \%$ in Montana vs. $90 \%$ in Texas) and CSPG production (97\% in Montana vs. $84 \%$ in Texas). Results from date-to-percent analyses indicated that $75 \%$ of Montana total, CSPG, and WSPG production were completed by 6 June, 10 June, and 12 July, respectively, and

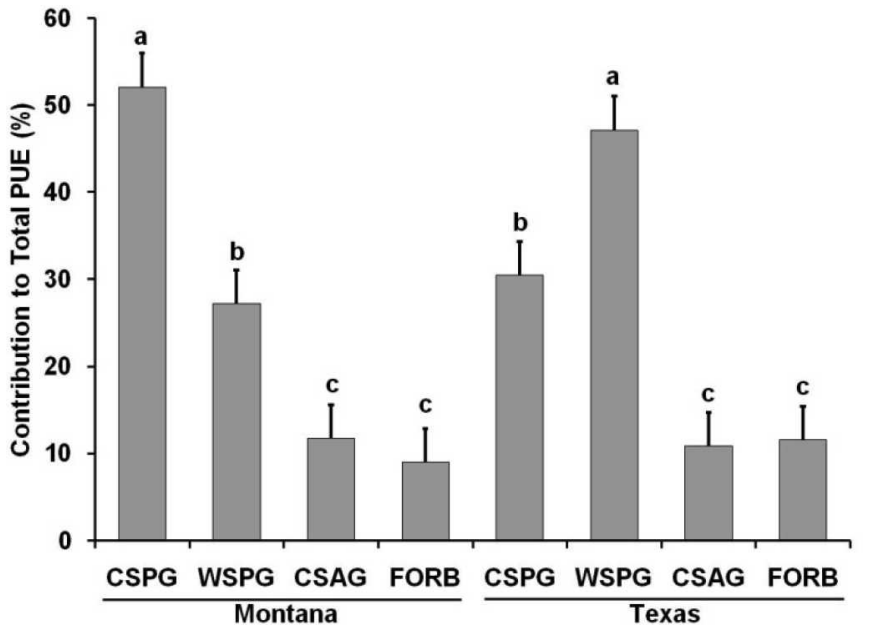

Figure 2. Mean contributions to precipitation use efficiencies (PUE; \%) and standard error bars by plant functional type (cool-season perennial grasses [CSPG], warm-season perennial grasses [WSPG], cool-season annual grasses [CSAG], and forbs [FORB]) for Miles City, Montana, and Throckmorton, Texas. Different letters above standard error bars indicate means differ $(P \leq 0.05)$.

$75 \%$ of Texas total, CSPG, and WSPG production were completed by 3, 20, and 15 July, respectively. Montana total, CSPG, and WSPG production were $90 \%$ completed by 1 July, 16 July, and 13 August, respectively, and $90 \%$ of Texas total, CSPG, and WSPG production were completed by 31 August, 15 October, and 9 September, respectively.

\section{Precipitation Use Efficiency}

Average PUE of total annual production was greater in Montana $\left(0.56 \mathrm{~g} \cdot \mathrm{m}^{-2} \cdot \mathrm{mm}^{-1}\right)$ than Texas $\left(0.40 \mathrm{~g} \cdot \mathrm{m}^{-2} \cdot \mathrm{mm}^{-1}\right)$. As the dominant species groups in Montana and Texas, differences in total PUE could largely be explained by CSPG and WSPG (Fig. 2). CSPG contributed more to total PUE than WSPG in Montana, whereas the opposite was true for Texas. Montana CSPG and Texas WSPG contributions were similar as were those from Montana WSPG and Texas CSPG. Percentages of Montana and Texas PUE estimates attributed to CSAG and FORB were similar $(11 \%)$ and low relative to other functional groups.

For the 1994-1995 Montana drought experiment (Table 1), PUE results are reported for the year drought was imposed and the following year. Ambient precipitation during late spring, summer, and early autumn of 1994 was well below average (Fig. 3), minimizing intended differences in total annual precipitation between treatments. Simulated May through September drought effects on PUE varied by year and PFT. PUE was greater with simulated drought than ambient treatment $\left(1.34 \mathrm{~g} \cdot \mathrm{m}^{-2} \cdot \mathrm{mm}^{-1}\right.$ vs. $\left.1.08 \mathrm{~g} \cdot \mathrm{m}^{-2} \cdot \mathrm{mm}^{-1}\right)$ in 1994 and similar $(P>0.05)$ between treatments $(0.87$ $\left.\mathrm{g} \cdot \mathrm{m}^{-2} \cdot \mathrm{mm}^{-1}\right)$ in 1995 . During both years, CSPG contributed more to PUE than did WSPG (Fig. 3). However, simulated drought reduced the percentage of PUE attributed to CSPG $19 \%$ and increased that of WSPG 53\%. Even under simulated drought conditions, CSPG made a greater contribution to PUE than WSPG. Percentage of PUE was similar between CSAG and FORB $(4 \%)$ and less than that of WSPG across years and drought treatments. 

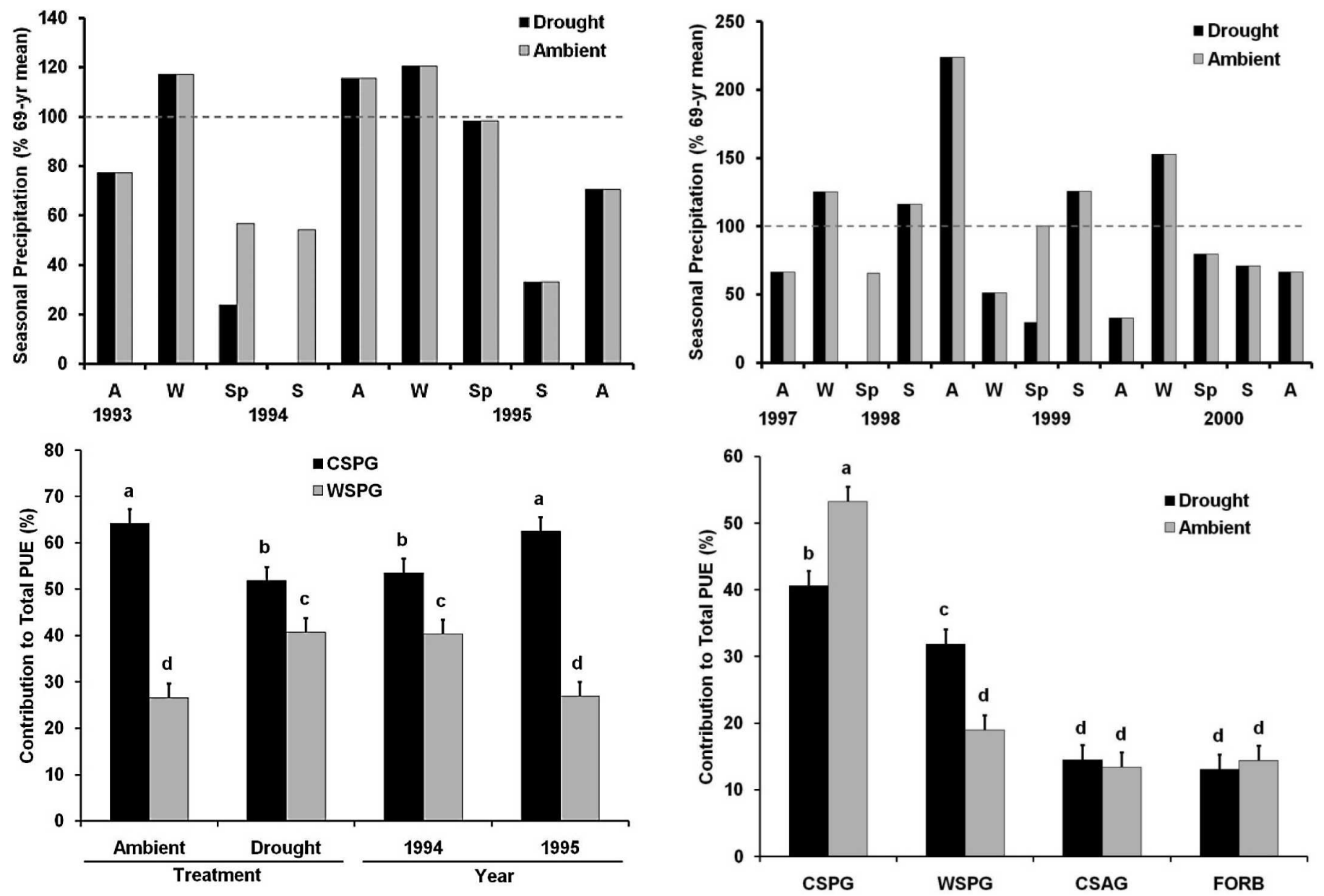

Figure 3. Autumn (A), winter (W), spring (Sp), and summer (S) proportional (percent of 69-yr mean) precipitation regimen for Montana simulated summer drought and ambient control treatments from autumn of 1993 through autumn of 1995 and mean contributions to precipitation use efficiency estimates (PUE; \%) and standard error bars for cool-season perennial grasses (CSPG) and warm-season perennial grasses (WSPG). Different letters above standard error bars indicate means differ $(P \leq 0.05)$ within a treatment or year.

The ambient and simulated spring droughts (April through June) of 1998-1999 had greater impact than the severe summer drought of 1994, with PUE and ANPP in 1998-2000 about $40 \%$ and $42 \%$ of $1994-1995$ estimates. Although both periods were generally dry, average precipitation was $21 \%$ less in 1994 and 1995 than $1998-2000$ (215 mm vs. $274 \mathrm{~mm}$ ). Total PUE estimates were similar across treatments and years for 1998 and $2000\left(0.32 \mathrm{~g} \cdot \mathrm{m}^{-2} \cdot \mathrm{mm}^{-1}\right)$. Simulated drought reduced total PUE in $1999\left(0.55 \mathrm{~g} \cdot \mathrm{m}^{-2} \cdot \mathrm{mm}^{-1}\right.$ vs. 0.67 $\mathrm{g} \cdot \mathrm{m}^{-2} \cdot \mathrm{mm}^{-1}$ ), but PUE estimates for ambient and drought treatments were greater than those for either treatment in 1998 and 2000. As with summer drought, CSPG contributed more to PUE than WSPG across treatments (Fig. 4). Drought reduced the portion of PUE attributed to CSPG $24 \%$, increased the contribution of WSPG $68 \%$, and had no effect on that of CSAG or FORB. The extremely wet autumn starting the 1999 growing season increased the portion of PUE from CSAG $128 \%$, whereas contributions from CSPG and WSPG decreased (Table 3).

Figure 4. Autumn (A), winter (W), spring (Sp), and summer (S) proportional (percent of 69-yr mean) precipitation regimen for Montana simulated spring drought and ambient control treatments from autumn of 1997 through autumn of 2000 and mean contributions to precipitation use efficiency estimates (PUE; \%) and standard error bars for cool-season perennial grasses (CSPG), warm-season perennial grasses (WSPG), coolseason annual grasses (CSAG), and forbs (FORB). Different letters above standard error bars indicate means differ $(P \leq 0.05)$.

The 2004 study was designed to quantify effects of aboveaverage summer precipitation on ANPP following spring drought. As in the previous studies, ambient precipitation was well below average when simulated drought conditions were imposed (Fig. 5). Severe spring drought reduced total PUE relative to all other treatments $\left(0.17 \mathrm{~g} \cdot \mathrm{m}^{-2} \cdot \mathrm{mm}^{-1}\right.$ vs. 0.28

Table 3. Percent contributions $( \pm 2.7 \%)$ to annual precipitation use efficiencies (PUE) for plant functional types cool-season perennial grasses (CSPG), warm-season perennial grasses (WSPG), cool-season annual grasses (CSAG), and forbs (FORB) near Miles City, Montana (1998-2000).

\begin{tabular}{lllcr}
\hline & \multicolumn{4}{c}{ Contribution to total PUE } \\
\cline { 2 - 5 } Year & CSPG & WSPG & CSAG & FORB \\
\hline & $54.7 \mathrm{a}^{1}$ & $29.7 \mathrm{c}$ & $10.2 \mathrm{ef}$ & $5.5 \mathrm{f}$ \\
1998 & $41.4 \mathrm{~b}$ & $17.4 \mathrm{de}$ & $23.3 \mathrm{~cd}$ & $17.9 \mathrm{~d}$ \\
1999 & $44.7 \mathrm{~b}$ & $29.3 \mathrm{C}$ & $8.3 \mathrm{f}$ & $17.7 \mathrm{~d}$ \\
\hline
\end{tabular}

${ }^{1}$ Means followed by different letters are significantly different $(P<0.05)$. 

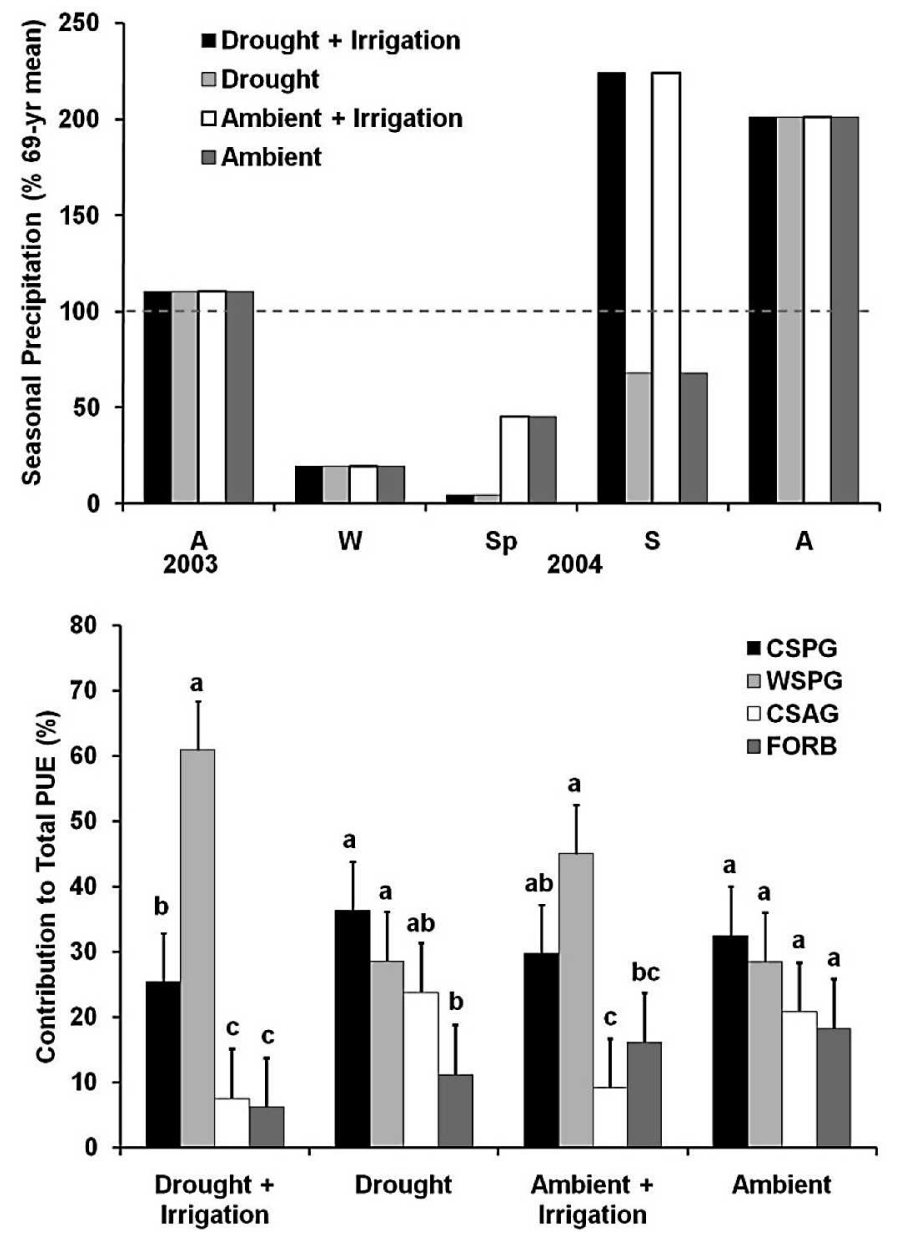

Figure 5. Autumn (A), winter (W), spring (Sp), and summer (S) proportional (percent of 69-yr mean) precipitation regimen for Montana simulated spring drought, simulated drought+summer irrigation, ambient control, and ambient control+irrigation treatments from autumn of 2003 through autumn of 2004 and mean contributions to precipitation use efficiency estimates (PUE; \%) and standard error bars for (cool-season perennial grasses [CSPG], warm-season perennial grasses [WSPG], cool-season annual grasses [CSAG], and forbs [FORB]). Different letters above standard error bars indicate means differ $(P \leq 0.05)$ within a treatment.

$\left.\mathrm{g} \cdot \mathrm{m}^{-2} \cdot \mathrm{mm}^{-1}\right)$. Interestingly, total PUE was similar among other treatments even though summer irrigation increased annual water received by $88 \mathrm{~mm}$ with spring drought and 153 $\mathrm{mm}$ with ambient spring conditions compared to ambient conditions throughout the year. Under ambient conditions of moderate spring drought, all PFT contributed similarly to total PUE (Fig. 5). FORB contributed less to total PUE than CSPG or WSPG with severe spring drought. Summer irrigation following moderate spring drought caused a shift in relative contributions to PUE, with CSPG becoming less dominant and WSPG exceeding CSAG and FORB. The majority of PUE was clearly attributed to WSPG and CSPG became secondary when severe spring drought was followed by summer irrigation. Contributions to PUE were similar across treatments for CSPG $(31 \%)$ and FORB (13\%). WSPG influence on PUE was greatest with severe drought plus irrigation, followed by moderate drought with summer irrigation, and least for both nonirrigated treatments.

\section{DISCUSSION}

\section{Precipitation}

Greater intensity of rain events in Texas could partially account for PUE being lower there than in Montana because more water is expected to be lost through runoff and not converted to plant biomass. At the Montana site, less than $1 \%$ of total precipitation was lost via deep percolation and surface runoff during a 4-yr period (Heitschmidt and Haferkamp 2003), whereas research at the Texas site showed losses averaged about $8 \%$ over a 3-yr period (Carlson et al. 1990). Alternatively, Wilcox et al. (2006) indicated water loss was less than $1 \%$ over an 8 -yr period near the Vernon, Texas, site. Differences during the study period might reflect that precipitation was above average in Texas and below average in Montana, but there is no indication water loss is inherently greater in Texas because of greater rainfall intensity.

\section{Aboveground Net Primary Production}

That ANPP was less in Montana than Texas was expected because average annual precipitation in Montana is about $46 \%$ of that in Texas and the two factors are known to be positively related (Sims and Singh 1978; Lauenroth 1979; Sala et al. 1988; Lauenroth and Sala 1992; Paruelo and Lauenroth 1996; Epstein et al. 1998; Lane et al. 1998; Lauenroth et al. 1999, 2000; Paruelo et al. 1999; O’Conner et al. 2001). Similarly, domination of the Montana site by CSPG and the Texas site by WSPG was expected based on differences in temperature and amount and distribution of precipitation (Fig. 1; Teeri and Stowe 1976; Paruelo and Lauenroth 1996; Epstein et al. 1997a, 1997b, 1998; Lauenroth et al. 1999). The $C_{3}$ grasses $(\mathrm{CSPG}+\mathrm{CSAG})$ were a greater component $(41 \%)$ of ANPP in Texas than might be expected, based purely on mean annual temperature and precipitation. However, mild temperatures typical of the study area during late winter, early spring, and early autumn are conducive to $\mathrm{C}_{3}$ grass production. Six of the Texas datasets were collected within honey mesquite stands, which provide optimal habitat for Texas wintergrass (Brock et al. 1978), the dominant $\mathrm{C}_{3}$ grass. Moreover, Texas wintergrass in this region increases in abundance with herbivory (Heitschmidt et al. 1985), and the 1978-1979 and 1981-1984 studies (i.e., 12 datasets) were conducted in grazed environments.

Credibility intervals (intervals in which the true value is estimated to be with $95 \%$ probability) for proportion of Montana ANPP produced narrowed considerably between July and September, but remained similar between dates for Texas ANPP. The difference in credibility intervals indicates the growing season was generally complete or near completion by 1 September in Montana, but could extend substantially beyond that date in Texas. Although WSPG are the dominant plants in Texas, CSPG, CSAG, and cool-season forbs can undergo substantial growth in late autumn and early winter, depending upon climatic conditions.

\section{Precipitation-Use Efficiency}

Greater contributions to PUE for CSPG in Montana and WSPG in Texas (Fig. 2) reflected that each location was dominated by species adapted to prevailing timing of precipitation (i.e., 
during cool springs in Montana and during warm springs and autumns in Texas). Generally minor ANPP by CSAG and FORB $\left(9 \mathrm{~g} \cdot \mathrm{m}^{-2}\right)$ ensured contributions to PUE estimates were low for each component across locations and most years. Had the temporal distribution of precipitation better coincided with establishment and growth conditions for CSAG and FORB, we would have expected that to be reflected in ANPP and its influence on PUE for those two components. In fact, the extremely wet autumn initiating the 1999 growing season caused CSAG contributions to PUE to more than double. However, that was the only time the Montana studies included a wet autumn conducive to annual grass production, and FORB production was limited by the generally dry springs across studies. Estimates of total PUE for Montana $(0.56$ $\mathrm{g} \cdot \mathrm{m}^{-2} \cdot \mathrm{mm}^{-1}$ ) were near the average of $0.61 \mathrm{~g} \cdot \mathrm{m}^{-2} \cdot \mathrm{mm}^{-1}$ reported from numerous other grassland sites (Lauenroth 1979; Sala et al. 1988; Lane et al. 1998; Lauenroth et al. 1999, 2000; Paruelo et al. 1999). Texas PUE $\left(0.40 \mathrm{~g} \cdot \mathrm{m}^{-2} \cdot \mathrm{mm}^{-1}\right)$ was less than average, but well within the range of reported values. Lauenroth et al. (2000) observed PUE to vary from 0.1 to 1.0 across the central Great Plains and O'Connor et al. (2001) reported PUE as $0.29,0.20$, and $0.08 \mathrm{~g} \cdot \mathrm{m}^{-2} \cdot \mathrm{mm}^{-1}$ for South African grasslands in good, medium, and poor condition, respectively. Although precipitation and ANPP were greater in Texas than Montana, this did not translate into greater PUE. Huxman et al. (2004) noted that PUE tended to decrease with increasing mean annual precipitation, but converge during dry periods. If such a difference could be expected due to the greater mean annual precipitation in Texas than Montana, then the effect should have been amplified by study period precipitation being $6 \%$ greater than average in Texas and $7 \%$ less than average in Montana. Additionally, differences in community structure between locations likely contributed to differences in PUE because O'Connor et al. (2001) observed species composition and precipitation explained about $63 \%$ of PUE variation in South Africa. Montana sites were dominated by large cool-season midheight grasses whereas shortgrasses and smaller midheight grasses were dominant at the Texas sites (Table 2). The presence of honey mesquite in the Texas (Vernon 1979-1980 and TER 1986-1988) study sites had inconsistent influence on PUE. Mesquite reduced herbage production about $30 \%$ in one study (Heitschmidt and Dowhower 1991) and had no effect on production or soil water in the other (Heitschmidt et al. 1986). Accounting for the mesquite-induced reduction in ANPP for three of the 22 Texas datasets indicates our PUE estimate of $0.40 \mathrm{~g} \cdot \mathrm{m}^{-2} \cdot \mathrm{mm}^{-1}$ could have been as high as $0.42 \mathrm{~g} \cdot \mathrm{m}^{-2} \cdot \mathrm{mm}^{-1}$, still considerably less than the $0.56 \mathrm{~g} \cdot \mathrm{m}^{-2} \cdot \mathrm{mm}^{-1}$ for Montana.

Results of Montana drought-irrigation experiments serve to emphasize the impact that seasonal precipitation patterns have on PUE and the mediating effects of PFT composition. CSPG generally contributed more to PUE estimates than WSPG because CSPG productivity was greater regardless of treatment or year $\left(125 \mathrm{~g} \cdot \mathrm{m}^{-1}\right.$ vs. $\left.70 \mathrm{~g} \cdot \mathrm{m}^{-2}\right)$. However, the relative changes in influence on PUE, such as the concurrent decrease for CSPG and increase for WSPG with the late spring and summer drought of 1994 and spring drought of 1998-1999, indicate that PUE is closely linked to the interactive temporal dynamics of growing season temperatures, availability of water, and the inherent physiological growth capacity of each species group. The clearest example was the shift from CSPG to WSPG as the major contributor to PUE following spring drought and summer irrigation. Several studies have focused on defining the fundamental relationships between the spatial distribution of PFT and environmental conditions such as precipitation, temperature, and soil texture (Teeri and Stowe 1976; Sims and Singh 1978; Paruelo and Lauenroth 1996; Epstein et al. 1997a, 1997b, 1998; Lauenroth et al. 1999), and O'Connor et al. (2001) determined that the compositional state of rangeland was the major influence on PUE. However, the results of this study elucidate the interacting effects that PFT composition and seasonal precipitation have on ANPP and PUE.

Decreased PUE attributed to CSPG during 1994-1995 was because of drought timing. In addition to summer and early autumn, the drought was imposed during late May and June, the primary growth period for CSPG. Although precipitation was naturally limited during spring, the drought treatments during this key period had significant ramifications for ANPP of CSPG. That CSPG contributions to PUE were reduced by spring drought in 1998 and 1999 was expected because annual precipitation was reduced about $30 \%$, and all of that reduction occurred during the period when $90 \%$ of CSPG ANPP is generally completed. In contrast, WSPG contributed more to PUE with drought and WSPG ANPP was relatively unchanged in either set of experiments. The 1994 drought reduced WSPG ANPP, but only during that year and the magnitude of change in ANPP was less than that in precipitation caused by the rainout shelter during a naturally dry period. The droughtinduced increase in WSPG contributions to PUE for the 19982000 experiments occurred because July through August precipitation was $156 \%$ and $184 \%$ of the long-term average following the spring droughts of 1998 and 1999, respectively, providing abundant water when temperatures were favorable for WSPG growth.

The 2004 drought-irrigation experiment results supported explanations for CSPG and WSPG responses to drought and timing of precipitation. CSPG and FORB each contributed similarly to PUE across treatments because supplemental water was applied after most growth typically occurs. Greater contributions to PUE for summer-irrigated WSPG following severe spring drought or moderate spring drought indicated the ability of this functional type to respond positively to an abundance of summer precipitation (Fig. 5). Moderate spring drought followed by summer irrigation produced intermediate PUE for WSPG, relative to nonirrigated plots and those with severe spring drought followed by summer irrigation, because impacts were moderated by spring precipitation that yielded less growth. Heitschmidt and Vermeire (2006) showed that WSPG productivity was greater with summer irrigation, regardless of spring precipitation. Although we observed PFT composition and influence on PUE could be altered with changes in the temporal distribution of water, the apparent ramifications of such a response on ANPP must be considered as well. WSPG productivity was greater with summer irrigation, regardless of spring precipitation. However, the shift in water distribution from spring to summer reduced total ANPP to less than half that during an 8-yr period with ambient spring and summer precipitation at the same location (Heitschmidt and Vermeire 2006). 
In addition to the measured variables, inequalities in evapotranspiration rates between locations and among seasons likely contributed to differences in ANPP and PUE. Structural and functional mechanisms directly enhancing plant water-use efficiencies also affect PUE at the individual plant and community level (Paruelo et al. 1999; Knapp and Smith 2001; Veron et al. 2002; Huxman et al. 2004). However, evapotranspiration rate is an overwhelming process affecting PUE in arid and semiarid ecosystems and is known to be positively related to mean annual temperature (Lauenroth and Burke 1995). Greater evapotranspiration rates undoubtedly provide partial explanation for less efficient precipitation use at the more mesic and warmer $\mathrm{C}_{4}$-dominated Texas sites than the more arid and cooler $\mathrm{C}_{3}$-dominated Montana grassland.

\section{IMPLICATIONS}

Results generally support the hypothesis that PUE varies between locations and among years and that many of the differences within a site are a function of PFT composition as it interacts with amount and seasonal distribution of precipitation. Processes, such as evapotranspiration, and inherent factors, such as soil texture, influence PUE, but plant growth requires that adequate water availability and appropriate temperatures coincide. Although PFT composition can be manipulated through management, the tendency will be for it to reflect prevailing weather patterns, as in the case of the $\mathrm{C}_{3^{-}}$ dominated Montana sites and $\mathrm{C}_{4}$-dominated Texas sites. Therefore, one should expect changes in ANPP and PUE to occur with shifts in timing and quantity of precipitation until the PFT composition becomes adjusted to the new regime.

\section{LITERATURE CITED}

Balley, R. G. 1995. Description of the ecoregions of the United States. 2nd ed. Washington, DC, USA: US Department of Agriculture, Forest Service Miscellaneous Publication No. 1391. 108 p.

Brock, J. H., R. H. HAAS, AND J. C. SHAVER. 1978. Zonation of herbaceous vegetation associated with honey mesquite in northcentral Texas. In: D. N. Hyder [ED.] Proceedings of the First International Rangelands Congress. Denver, CO, USA Society for Range Management. p. 187-189.

Caldwell, M. M., R. S. White, R. T. Moore, and L. B. Camp. 1977. Carbon balance, productivity, and water use of cold-winter desert shrub communities dominated by $\mathrm{C}_{3}$ and $\mathrm{C}_{4}$ species. Oecologia 29:275-300.

Carlson, D. H., T. L. Thurow, R. W. Knight, and R. K. Heitschmidt. 1990. Effect of honey mesquite on the water balance of Texas Rolling Plains rangeland. Journal of Range Management 43:491-496.

Digital Visual Fortran [computer program]. 2000. Houston, TX, USA: Compaq Computer Corporation.

Epstein, H. E., W. K. Lauenroth, and I. C. Burke. 1997a. Effects of temperature and soil texture on ANPP in the U.S. Great Plains. Ecology 78:2628-2631.

Epstein, H. E., W. K. Lauenroth, I. C. Burke, and D. P. Coffin. 1997b. Productivity patterns of $\mathrm{C}_{3}$ and $\mathrm{C}_{4}$ functional types in the U.S. Great Plains. Ecology 78:722-731.

Epstein, H. E., W. K. Lauenroth, I. C. Burke, and D. P. Coffin. 1998. Regional productivity patterns of plant species in the Great Plains of the United States. Plant Ecology 134:173-195.

Frederick, K. D. 1993. Climate change impacts on water resources and possible responses in the mink region. Climatic Change 24:83-115.

Gelman, A., J. B. Carlin, H. S. Stern, and D. B. Rubin. 2004. Bayesian data analysis. 2nd ed. Boca Raton, FL, USA: Chapman \& Hall/CRC. 696 p.
Hatfield, J. L., T. J. Saucr, and J. H. Prueger. 2001. Managing soils to achieve greater water use efficiency: a review. Agronomy Journal 93:271-280.

Heitschmidt, R. K., AND S. L. Dowhower. 1991. Herbage response following control of honey mesquite within single tree lysimeters. Journal of Range Management 44:144-149.

Heitschmidt, R. K., S. L. Dowhower, R. A. Gordon, and D. L. Price. 1985. Response of vegetation to livestock grazing at the Texas Experimental Ranch. College Station, TX, USA: The Texas A\&M University System, Texas Agricultural Experiment Ranch Bulletin B-1515. $34 \mathrm{p}$

Heitschmidt, R. K., S. L. Dowhower, and J. W. Walker. 1987. 14- vs. 42-Paddock rotational grazing: aboveground biomass dynamics, forage production, and harvest efficiency. Journal of Range Management 40:216-223.

Heitschmidt, R. K., E. E. Grings, M. R. Haferkamp, and M. G. Karl. 1995. Herbage dynamics on two Northern Great Plains range sites. Journal of Range Management 48:211-217.

Heitschmidt, R. K., and M. R. Haferkamp. 2003. Ecological consequences of drought and grazing on grasslands of the northern Great Plains. In: J. F. Weltzin and G. R. McPherson [EDS.]. Changing precipitation regimes and terrestrial ecosystems. Tucson, AZ, USA: University of Arizona Press. p. 107-126.

Heitschmidt, R. K., M. R. Haferkamp, M. G. Karl, and A. L. Hild. 1999. Drought and grazing 1. Effects on quantity of forage produced. Journal of Range Management 52:440-446.

Heitschmidt, R. K., K. D. Klement, and M. R. Haferkamp. 2005. Interactive effects of drought and grazing on Northern Great Plains rangelands. Rangeland Ecology and Management 58:11-19.

Heitschmidt, R. K., D. L. Price, R. A. Gordon, and J. R. Frasure. 1982. Short duration grazing at the Texas Experimental Ranch: effects on aboveground net primary production and seasonal growth dynamics. Journal of Range Management 35:367-372.

Heitschmidt, R. K., R. D. Schultz, and C. J. Scifres. 1986. Herbaceous biomass dynamics and net primary production following chemical control of honey mesquite. Journal of Range Management 39:67-71.

Heitschmidt, R. K., and L. T. Vermeire. 2006. Can abundant summer precipitation counter losses in herbage production caused by spring drought? Rangeland Ecology \& Management 59:392-399.

Huxman, T. E., M. D. Smith, P. A. Fay, A. K. Knapp, M. R. Shaw, M. E. Lolk, S. D. Smith, D. T. Tissue, J. C. Zak, J. F. Weltzin, W. T. Pockman, O. E. Sala, B. M. Haddad, J. Harte, G. W. Koch, S. Schwinning, E. E. Small, and D. G. Williams. 2004. Convergence across biomes to a common rain-use efficiency. Nature 429:651-654.

JoERNS, J. 0. 1961. Investigation of the sources of natural pollution: Wichita River basin above Lake Kemp, Texas, 1951-1957. Austin, TX, USA: US Geological Survey, Water Resources Division, Open File Release No. 62. 32 p.

Knapp, A. K., AND M. D. Smith. 2001. Variation among biomass in temporal dynamics of aboveground primary production. Science 291:481-484.

Lane, D. R., D. P. Coffin, and W. K. Lauenroth. 1998. Effects of soil texture and precipitation on above-ground net primary productivity and vegetation structure across the Central Grassland region of the United States. Journal of Vegetation Science 9:239-250.

LAUENROTH, W. K. 1979. Grassland primary production: North American grasslands in perspective. In: N. R. French [ED.]. Perspectives in Grassland Ecology. New York, NY, USA: Springer-Verlag. p. 3-24.

Lauenroth, W. K., and I. C. Burke. 1995. Great Plains, climate variability. In: W. A. Nierenberg [ED.]. Encyclopedia of Environmental Biology. Volume 2. San Diego, CA, USA: Academic Press. p. 237-249.

Lauenroth, W. K., I. C. Burke, and M. P. Gutmann. 1999. The structure and function of ecosystems in the Central North American grassland region. Great Plains Research 9:223-259.

Lauenroth, W. K., I. C. Burke, and J. M. Paruelo. 2000. Patterns of production and precipitation-use efficiency of winter wheat and native grasslands in the Central Great Plains of the United States. Ecosystems 3:344-351.

Lauenroth, W. K., and O. E. Sala. 1992. Long-term forage production of North American shortgrass steppe. Ecological Applications 2:397-403. 
Le Houerou, H. N. 1984. Rain use efficiency: a unifying concept in arid-land ecology. Journal of Arid Environments 7:213-247.

Le Houerou, H. N., R. L. Bingham, And W. Skerbek. 1988. Relationship between the variability of primary production and the variability of annual precipitation in world arid lands. Journal of Arid Environments 15:1-18.

McNaughton, S. J., O. E. Sala, and M. Oesterheld. 1993. Comparative ecology of African and South American arid to subhumid ecosystems. In: P. Goldblatt [ED.]. Biological relationships between Africa and South America. New Haven, CT, USA: Yale University Press. p. 548-567.

Monson, R. K., M. R. Sackschewsky, and G. J Williams, III. 1986. Field measurements of photosynthesis, water-use efficiency, and growth in Agropyron smithii $\left(\mathrm{C}_{3}\right)$ and Bouteloua gracilis $\left(\mathrm{C}_{4}\right)$ in the Colorado shortgrass steppe. Oecologia 68:400-409.

Nielsen, D. C., P. W. Unger, and P. R. Miller. 2005. Efficient water use in dryland cropping systems in the Great Plains. Agronomy Journal 97:364-372.

[NOAA] National Oceanic and Atmospheric Administration. 1988. Climatological data annual summary Texas 1978-1988. Volumes 81-91. Asheville, NC, USA: US Department of Commerce.

[NOAA] National Oceanic and Atmospheric Administration. 2004. Climatological data annual summary Montana 1992-2004. Volumes 95-107. Asheville, NC, USA: US Department of Commerce.

Noy-Meir, I. 1973. Desert ecosystems: environment and producers. Annual Review of Ecology and Systematics 4:25-51.

O'Connor, T. G., L. M. Haines, And H. A. Snyman. 2001. Influence of precipitation and species composition on phytomass of a semi-arid African grassland. Journal of Ecology 89:850-860.

Paruelo, J. M., and W. K. Lauenroth. 1996. Relative abundance of plant functional types in grasslands and shrublands of North America. Ecological Applications 6:1212-1224.

Paruelo, J. M., W. K. Lauenroth, I. C. Burke, and O. E. Sala. 1999. Grassland precipitation-use efficiency varies across a resource gradient. Ecosystems 2:64-68.
Rosensweig, M. L. 1968. Net primary productivity of terrestrial communities: prediction from climatological data. American Naturalist 6:1212-1224.

RutheRFoRD, M. C. 1980. Annual plant production-precipitation relations in arid and semiarid regions. South African Journal of Science 76:53-56.

Sala, 0. E., W. J. Parton, L. A. Joyce, and W. K. Lauenroth. 1988. Primary production of the central grassland region of the United States. Ecology 69:40-45.

SAS. 1990. SAS/STAT User's Guide. Version 6, Volume 2. Cary, NC, USA: SAS Institute, Inc. $1686 \mathrm{p}$.

Sims, P. L., AND J. S. Singh. 1978. The structure and function of ten western North American grasslands. Journal of Ecology 66:573-597.

Singh, J. S., W. K. Lauenroth, and R. K. Steinhorst. 1975. Review and assessment of various techniques for estimating net aerial primary production in grasslands from harvest data. Botany Review 41:181-232.

SmoLıAK, S. 1986. Influence of climatic conditions on production of Stipa-Bouteloua prairie over a 50-year period. Journal of Range Management 39:100-103.

Teeri, J. A., And L. G. Stowe. 1976. Climatic patterns and the distribution of $\mathrm{C}_{4}$ grasses in North America. Oecologia 23:1-12.

Veron, S. R., J. M. Paruelo, O. E. Sala, and W. K. Lauenroth. 2002. Environmental controls of primary production in agricultural systems of the Argentine Pampas. Ecosystems 5:625-635.

Webb, W. L., W. K. Lauenroth, S. R. Szarek, and R. S. Kinerson. 1983. Primary production and abiotic controls in forests, grasslands, and desert ecosystems in the United States. Ecology 64:134-151.

Webb, W. L., S. Szarek, W. K. Lauenroth, R. B. Kinerson, and M. Smith. 1978. Primary productivity and water use in native forest, grassland, and desert ecosystems. Ecology 59:1230-1247.

Wilcox, B. P., S. L. Dowhower, W. R. Teague, and T. L. Thurow. 2006. Long-term water balance in a semiarid shrubland. Rangeland Ecology and Management 59:600-606.

Winslow, J. C., E. R. Hunt, and S. C. Piper. 2003. The influence of seasonal water availability on global $\mathrm{C}_{3}$ versus $\mathrm{C}_{4}$ grassland biomass and its implications for climate change research. Ecological Modelling 163:153-173. 